\title{
THE UTILIZATION OF SYNTHETIC METHIONINE IN BROILER CHICKEN PRODUCTION: EFFECT ON GROWTH PERFORMANCE, BLOOD AND CARCASS CHARACTERISTICS
}

\author{
P. O. OZUNG, M. I. ANYA, O. O. K. OKO, P. O. EBURU, E. A. AGIANG AND N. A. EKPAH
}

(Received 28 July 2017; Revision Accepted 10 November 2017)

\begin{abstract}
An 8-week feeding trial was carried out to evaluate the effect of graded levels of synthetic methionine on the growth performance, blood and carcass characteristics of broiler chickens. A total of 120 day-old chicks of Amobyn strain with mean body weight of $36.67 \mathrm{~g}$ were randomly divided into four groups of 30 chicks each to constitute treatments $\mathrm{T}_{1}(0 \%$ control), $\mathrm{T}_{2}(0.20 \%$ methionine $), \mathrm{T}_{3}(0.40 \%$ methionine $)$ and $\mathrm{T}_{4}(0.60 \%$ methionine $)$, respectively. Each group was further divided into three replicates of 10 birds each in a Completely Randomized Design (CRD). Feed and water were provided ad libitum and all the birds were managed on a deep litter floor under the same environmental conditions for 56 days. All data were subjected to One- way analysis of variance and significant mean values were separated using Duncan Multiple Range Test. The results obtained for starter broiler chickens showed that total feed intake, weekly feed intake, daily feed intake and feed conversion ratio were significantly $(P<0.05)$ influenced by dietary treatments while the results for finisher chickens showed that only the final body weight was significantly $(P<0.05)$ influenced. The blood characteristics showed that monocytes, mean corpuscular volume and mean corpuscular haemoglobin concentration were significantly $(P<0.05)$ influenced by dietary treatments. The serum biochemical indices showed no significant $(P>0.05)$ differences between dietary treatments on all parameters. Carcass characteristics showed significant $(P<0.05)$ differences between dietary treatment in pre- slaughter weight, lungs weight, intestinal length, intestinal weight as well as weight of spleen and oesophagus. Therefore, this study concludes that synthetic methionine can be included in the diets of broiler chickens up to $0.60 \%$ without detrimental effects on their growth performance, blood and carcass characteristics.
\end{abstract}

KEYWORDS: Synthetic methionine, chicken, growth, blood, carcass

\section{INTRODUCTION}

Broiler chicken production has remained one of the viable options of achieving sustainable and rapid production of high quality animal protein to meet the demands of Nigerian teeming population (Apata and Ojo, 2000). However, the major constraint to poultry production is the high cost of energy and protein concentrates. Church (1991) observed that $75 \%$ of the cost of raising or maintaining poultry is attributable to feeds and feeding. Feed cost alone in poultry enterprise is about $70 \%$ of the total cost of production (Ogunfowora, 1984) which has been attributed to over dependence on the conventional plant protein feed stuffs such as soybean and groundnut cake (Emenalon and Udedibie, 1998). However, poultry nutrition has improved tremendously for the past few decades. In spite of advances made on the nutritional aspect, a lot of nutritional problems are still unsolved and serve as a challenge to investigators in this field worldwide.

One of the most important areas in broiler chicken production is amino acid nutrition. One of the essential amino acids required by broiler chickens is methionine and it is usually first limiting in diets based on maize and soybean meal (Fancher and Jesen, 1989). One major cause of methionine deficiency is the fact that large amounts of plant protein supplements are used in feeds plus low levels of animal and fish proteins (North and Bell, 1990). Extant reports have shown that it is more economical to add synthetic methionine than more soybean meal or other natural protein sources to meet the requirement of broiler chickens. According to Olomu (1995), deficiency of this amino acid can lead to reduced appetite, retarded growth and poor feed

P. O. Ozung, Department of Animal Science, Faculty of Agriculture, Forestry \& Wildlife Resources Management, University of Calabar, Calabar, Nigeria.

M. I. Anya, Department of Animal Science, Faculty of Agriculture, Forestry \& Wildlife Resources Management, University of Calabar, Calabar, Nigeria.

O. O. K. Oko, Department of Animal Science, Faculty of Agriculture, Forestry \& Wildlife Resources Management, University of Calabar, Calabar, Nigeria.

P. O. Eburu, Department of Animal Science, Faculty of Agriculture, Forestry \& Wildlife Resources Management, University of Calabar, Calabar, Nigeria.

E. A. Agiang, Department of Animal Science, Faculty of Agriculture, Forestry \& Wildlife Resources Management, University of Calabar, Calabar, Nigeria.

N. A. Ekpah, Department of Animal Science, Faculty of Agriculture, Forestry \& Wildlife Resources Management, University of Calabar, Calabar, Nigeria. 
efficiency. Previous studies with lower levels of methionine inclusion (Swain and Johri, 2000; Deng et al., 2007; Kabalde et al., 2009) have proved that there is no significant difference in growth performance and carcass yield of broiler chickens. There is also paucity of research findings on the haematological characteristics of broiler chickens based on synthetic methionine inclusion. This study was therefore undertaken to determine the effect of dietary synthetic methionine inclusion on the growth performance, blood and carcass characteristics of broiler chickens in a tropical niche.

\section{MATERIALS AND METHODS}

\section{Location of the Study}

The study was carried out at the Poultry Unit of the Teaching and Research Farm, Department of Animal
Science, University of Calabar, Calabar, Cross River State. Calabar is located at latitude $3^{0} \mathrm{~N}$ and longitude $7^{0}$ E. It occupies a land mass of $233.25 \mathrm{sq}$ miles $\left(604 \mathrm{~km}^{2}\right)$. It has a rainfall average of $1.830 \mathrm{~mm}$ per annum, average temperature of $24^{\circ} \mathrm{C}$.

\section{Experimental Diets}

Four experimental diets were formulated each at the starter and finisher phases of the study, respectively. Starter diets were given from 0-4 weeks to the birds while the finisher diets were given from 5-8 weeks. Synthetic methionine was ordered from a reputable distributor in Calabar and included in the diets at $0,0.20$, 0.40 and $0.60 \%$ levels for $T_{1}$ (control), $T_{2}, T_{3}$ and $T_{4}$, respectively. The gross composition of experimental diets is shown in Tables 1 and 2, respectively for starter and finisher

phases.

Table 1: Gross Composition of Experimental Diets (Starter Phase)

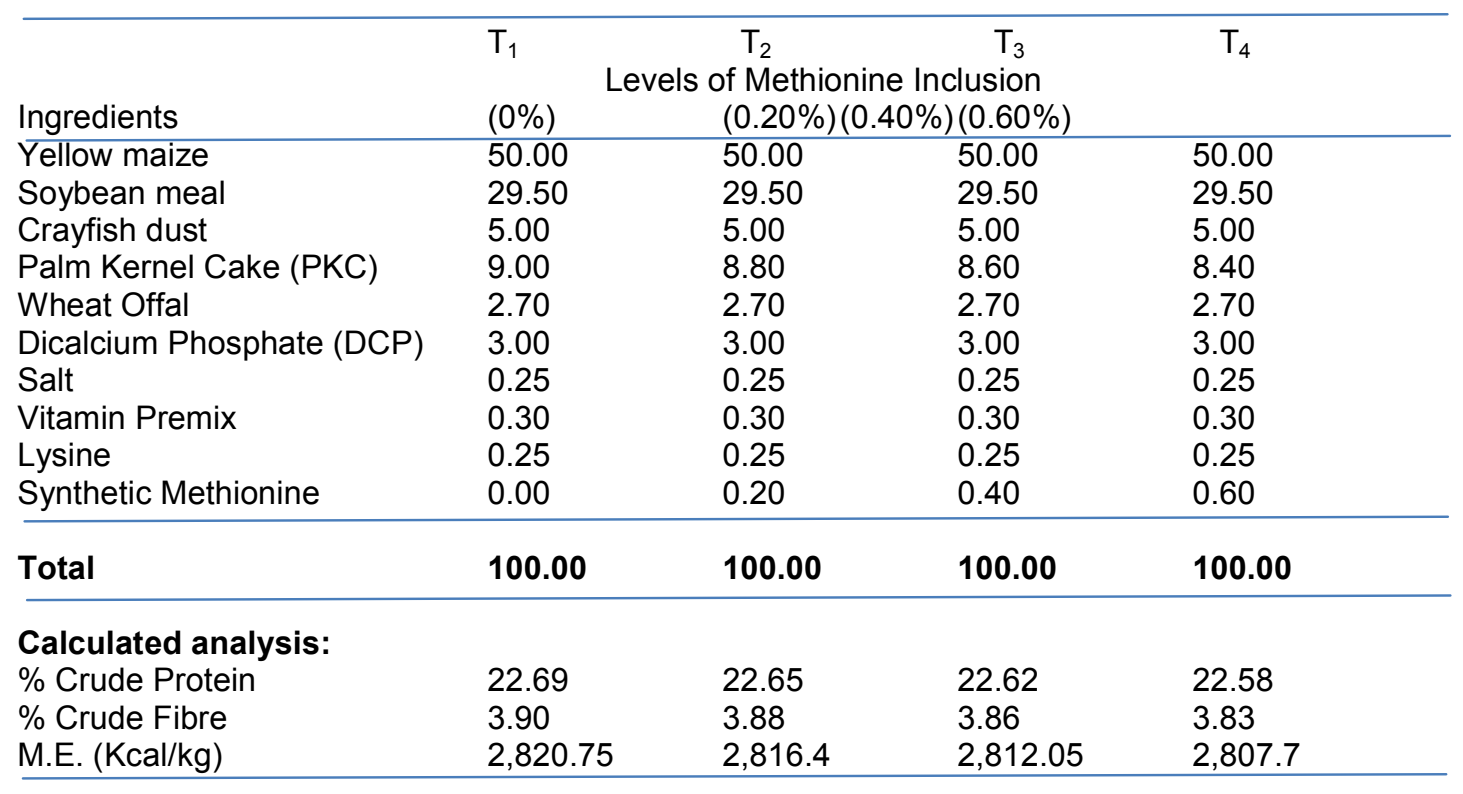

Gross composition of Bio: Supreme Broiler Premix

Vitamin A $\quad-12,000$ 000l. U, Vit D3 - 3,000 000 I. U, Vit E-30, 000mg, Vit. k3-2500mg, Folic Acid-100mg, Niacin-40,000mg,Calpan-10.000mg,Vit.B2 50,000mg, vit.B12-20mg, Vit B1 - 2000mg,Vit. B6 -3500mg, Biotin $80 \mathrm{mg}$

Antioxidant -125, 00mg, Cobalt -250mg, selenium - 250mg, lodine-1200mg, Iron 40 000mg,Manganese-70,000mg, Copper-8,000mg, Zinc -60, 000mg, Choline chlorides - 200,00omg. Manufactured by Animal Care Services Konsuit (Nigeria). LTD. 
Table 2: Gross Composition of Experimental Diets (Finisher Phase)

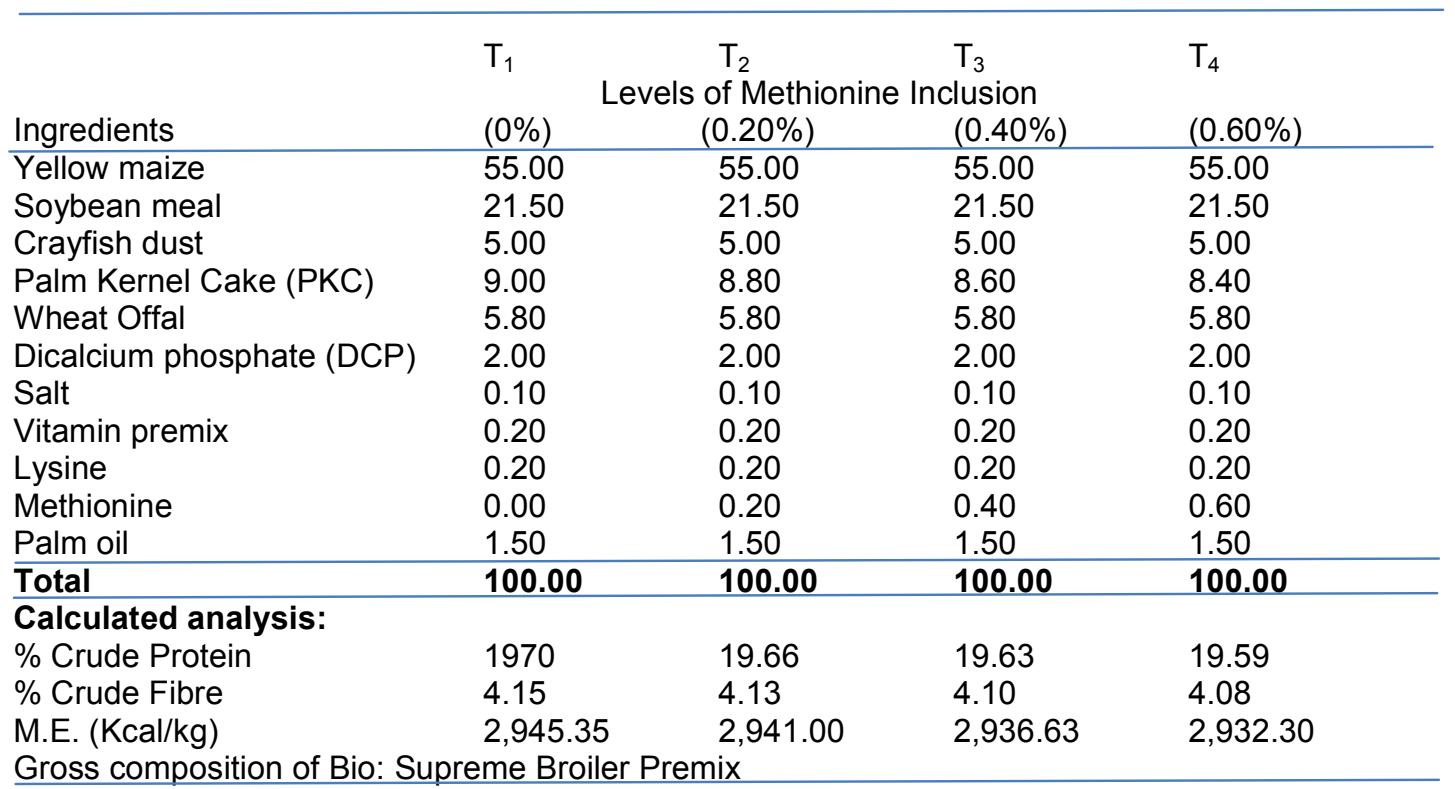

Vitamin A $-12,000$ 000I. U, Vit D3 - 3,000 000 I. U, Vit E-30, 000mg, Vit. k3-2500mg, Folic Acid-100mg,

Niacin-40,000mg,Calpan-10.000mg,Vit.B2 50,000mg, vit.B12-20mg, Vit B1 - 2000mg, Vit. B6 -3500mg, Biotin $80 \mathrm{mg}$

Antioxidant -125, 00mg, Cobalt -250mg, selenium - 250mg, lodine-1200mg, Iron 40 000mg,Manganese-70,000mg, Copper-8,000mg, Zinc -60, 000mg, Choline chlorides - 200,00omg.

Manufactured by Animal Care Services Konsuit (Nigeria). LTD.

\section{Proximate analysis}

The proximate analysis of the experimental diets was carried out based on standard methods of AOAC (2000).

\section{EXPERIMENTAL PROCEDURE}

Experimental animals, management and experimental design

One Hundred and Twenty (120) day-old chicks of Amobyn strain were purchased from a reputable distributor in Calabar and used in this study. All chicks were brooded and fed the experimental diets. Feed and water were provided ad libitum until they were eight (8) weeks old. During the feeding trial, the chicks were housed in a deep litter floor with adequate spacing, ventilation and protection against predators and other environmental conditions were ensured. Chicks were vaccinated against Newcastle and infectious bursal diseases and other routine management procedures for broiler chicks were also carried out. The chicks were divided into four groups of 30 each. The chicks were randomly allotted to the dietary treatments $\left(T_{1}, T_{2}, T_{3}\right.$ and $\mathrm{T}_{4}$ ) using a Completely Randomized Design (CRD) with 3 replicates per treatment of 10 chicks each.

\section{Feed intake}

Feed intake was determined on a daily basis as the difference between the quantity offered and the quantity left over the following morning. Weight gain/change was calculated by difference.

\section{Body weight}

Initial body weights of the birds were taken at the start of the trial and subsequently live weight measurements were carried out on a weekly basis. Weight gain was calculated by difference.

Feed conversion ratio (FCR)

Feed Conversion Ratio was calculated as the ratio of feed intake over body weight gain.

Blood collection and evaluation of blood parameters At the end of the feeding trial (eighth week), fifteen birds (5 per replicate) from each treatment group were randomly selected for blood collection. About $2 \mathrm{ml}$ of blood were collected per bird. The collection was done by puncturing the brachial vein with a $5 \mathrm{ml}$ scalp vein needle and syringe, two separate blood samples were collected immediately, one sample into a set of sterile plastic bottles, containing ethylene diamine tetra acetic acid (EDTA) as the anticoagulant for determination of haematological parameters and the other into unheparinised tubes for the determination of serum biochemical indices.

\section{White Blood Cell Counts (WBCs)}

White Blood Cell Counts were estimated by the haemocytometry method as described in Dacie and Lewis (1991). The differential counts of white blood cells were determined by making a differential smear, using Leishman stain for 10 minutes after which it was washed off with tap water, then allowed to dry and viewed with $\mathrm{x} 100$ objective microscope and the percentage Lymphocytes, Eosinophils, Neutrophils, Basophils and Monocytes, respectively were determined.

\section{Red Blood Cell Counts (RBCs)}

Red Blood Cell Counts were determined using the haemocytometer. Haematocrit and Haemoglobin $(\mathrm{Hb})$ 
values were measured by micro-haematocrit method (Kececi et al., 1998). The standard ratio of the mean Corpuscular Haemoglobin Concentration (MCHC) was calculated according to the method described by Jain (1986).

\section{Packed Cell Volume (PCV)}

The anticoagulant (EDTA) treated blood samples were allowed to enter the capillary tubes two-third full. Other ends of the tubes were sealed by heating. The tubes were then centrifuged and PCV values were read from a haematocrit reader. The results were reported in percentage as described by Kelly (1980).

\section{Determination of serum biochemical characteristics} Blood samples collected for serum biochemical determination were centrifuged to obtain serum. Sera samples were analysed for total protein, cholesterol and globulin using Spectrophotometry methods and Randox Test Kits were used for protein and albumin determinations, respectively.

\section{Carcass evaluation}

At the end of $8^{\text {th }}$ week, eighteen (18) birds per treatment (6 per replicate) whose weight were equal or close to the overall mean weight of the group were tagged and taken from each treatment for carcass evaluation. The birds were starved overnight with ample supply of drinking water. Each bird was weighed separately the following morning and slaughtered by severing the jugular and carotid veins after which they were allowed to bleed and followed by scalding at about $70^{\circ} \mathrm{C}$. Plucking of feathers was carried out manually and carefully to avoid tearing the skin. The weight of each bird was taken after bleeding and plucking. The plucked carcasses were dissected and eviscerated by removing the internal organs, the head and the shanks. The head, shanks and the internal organs, i.e. intestine, crop, proventriculus, gizzard, kidney, liver, heart and lungs were separately weighed using a sensitive electronic balance and likewise the eviscerated carcass. The eviscerated carcass was carefully cut into major parts like thighs, drumsticks, breast, and back and weighed separately. The respective weights of different parts of the chickens were recorded and expressed as a percentage of live weight of the birds.

\section{Statistical Analysis}

The data obtained in this study were subjected to Oneway Analysis of Variance for CRD using SPSS statistical software. Significant mean values were separated using the Duncan multiple range test (DMRT) (Steel and Torrie, 1980).

\section{RESULTS}

Table 3 shows the proximate composition of the overall experimental diets. The dry matter content of the diets was between 83.00 and $85 \%$ for starter as well as 83.00 and $86.00 \%$ for finisher diets. The crude protein ranged from $20.12-21-12 \%$ for starter while $19.12-19.5 \%$ were recorded for finisher. The value of $2.00-3.00 \%$ and 1.75 - $2.50 \%$ respectively for starter and finisher were recorded for ether extract. Crude fibre value ranged from $6.41-6.50 \%$ for starter and $7.00 \%$ for finisher. Nitrogen free extract had the range of $59.90-65.88 \%$ for starter and $66-15-67.00 \%$ of finisher. Results of the growth performance characteristics of broiler starter fed diets with graded levels of methionine are presented in Table 4. The results showed that birds with $0.40 \%$ methionine was significantly higher $(p>0.05)$ than the rest of the treatment group except birds on diet with $0.20 \%$ in terms of feed intake. Total feed intake, average weekly feed intake, daily feed intake and feed conversion ratio were significantly $(p<0.05)$ influenced by dietary treatments while total weight gain, average daily weight gain were not significantly $(p>0.05)$ influenced by dietary treatments. Performance characteristics of broiler finishers fed diets with graded levels of methionine are summarized in Table 5 . The results revealed that total weight gain, average weekly weight gain, and average daily weight gain, total feed intake, average weekly feed intake, average daily feed intake and feed conversion ratio were significantly $(p<0.05)$ affected by dietary treatments. When compared with the control diet, the highest values for total weight gain and average daily weight gain were recorded in the dietary treatment $\left(T_{4}\right)$ with $0.60 \%$ synthetic methionine inclusion. Table 6 summarizes the results of carcass characteristics of broilers fed graded levels of methionine in maizesoybean based-diets. The results showed that preslaughter weight (live weight), lungs, intestinal length and intestinal weight were significantly influenced $(p<0.05)$ by dietary treatments. The results of the effect of graded level of synthetic methionine on the haematological characteristics are presented in Table 7, while Table 8 shows the results of serum bio-chemical indices of broilers. The results of the haematological indices revealed that only monocytes, MCV and $\mathrm{MCHC}$ were significantly $(p<0.05)$ influenced by dietary treatments. The dietary treatments had no significant $(p>0.05)$ influence on all of the serum biochemical indices.

\section{DISCUSSION}

\section{Proximate composition of experimental diets}

The proximate composition of experimental diets (Table 3) showed that the dry mater in the control diets was $86.00 \%$ for finisher. The crude protein levels recorded for diet with $0.20 \%$ methionine $(21.12$ and $19.50 \%)$ for starter and finisher while the least (20.12 and $19.12 \%)$ was recorded respectively for diets with $0 \%$ and $0.60 \%$ methionine. These values were not statistically different $(P>0.05)$, but were however lower than $25 \%$ and $20 \%$ crude protein reported by Dafwang (2006). The highest value of ether extract was obtained with diet with $0.20 \%$ (3\%) for starter while the least was recorded for diet with $0.60 \%$ methionine. In the finisher diet, the highest was recorded for diets with $0.40 \%$ methionine $(2.50 \%)$ while the control had the least $(1.75 \%)$. Crude fibre was highest with diets with $0 \%, 0.40 \%$ and $0.60 \%$ methionine while those with $0.20 \%$ methionine had the least for starter diets. Same value was recorded for the finisher diets. Diets with $0.40 \%$ and $0.60 \%$ methionine had the highest ash content for starter diets while the control diet and diets with $0.20 \%$ methionine had the least $(52 \%)$. Same value was recorded for the finisher diets (5). Nitrogen free extract was highest in the control diets $(65.88 \%, 67.00 \%)$ for both starter finishers while the least was recorded in diet with $0.40 \%$ methionine $(59.90$, $66.13 \%)$ for both starter finisher diets. 
Table 3: Proximate Composition of Experimental Diets

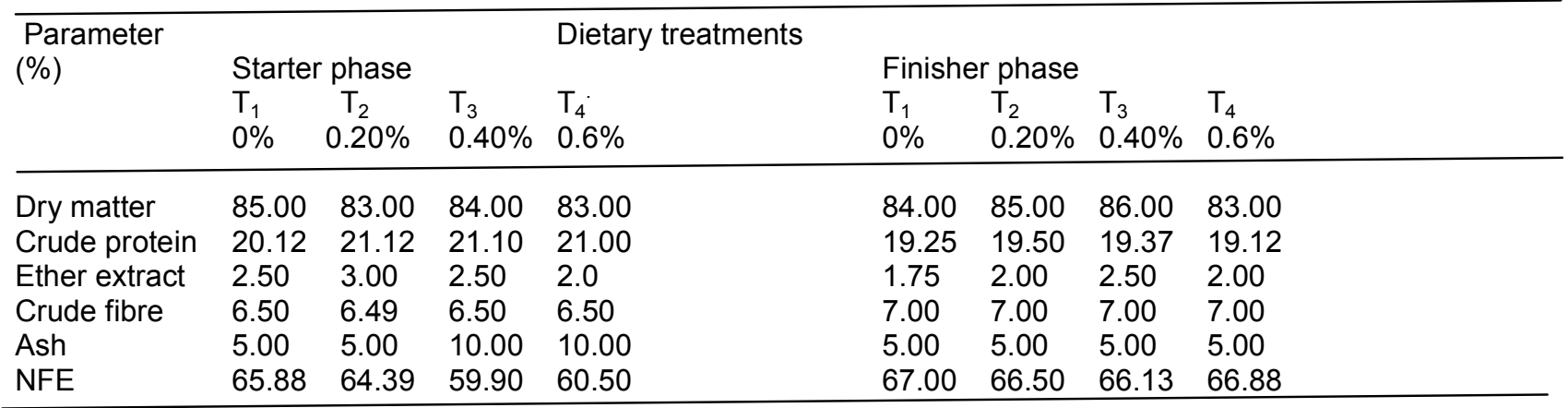

Growth performance characteristics of broiler chickens (Starter Phase)

The total feed intake (Table 4$)$ was significantly $(p<0.05)$ influenced by dietary treatments. Birds on the control diets consumed significantly higher feed (2694.95g) followed by birds on $0.60 \%$ methionine with $2673.20 \mathrm{~g}$, $0.40 \%$ methionine with $2227.22 \mathrm{~g}$ while those on $0.20 \%$ with $2160.58 \mathrm{~g}$ consumed significantly low feed. These values were much higher than $1215 \mathrm{~g}$ obtained for broilers at week 4 by Dafwang (2006) and the range of 1005.06 - 1143.09g reported by Afolayan et al. (2014). Average weekly feed intake and average daily feed intake followed the same trend with the control group consuming significantly higher feed on weekly and daily basis $(673.74 \mathrm{~g}$ and $96.24 \mathrm{~g}$ ) while birds on diets with $0.20 \%$ methionine consume significantly the least feed $(540.15 \mathrm{~g}$, and $77.16 \mathrm{~g})$ weekly and daily respectively. Feed conversion ratio were significantly $(p<0.05)$ influenced by dietary treatments. Diets with $0.20 \%$ and $0.40 \%$ which resulted in a ration that is better utilized than the other ration by the birds given their low feed conversion ratio values of 3.87 and 3.52 respectively. According to Etuk and Udedibie (2003); Akinmutimi (2003); Amaefule and Onwudike (2003); Ani and Okeke (2003); Esonu et al. (2003) the most important factor influencing the performance of poultry birds is the quality of the feed offered to the birds.

Table 4: Growth Performance Characteristics of Broiler Chickens fed graded levels of synthetic Methionine in maizesoybean based diet (starter phase)

\begin{tabular}{llllll}
\hline Parameter (g/bird) & \multicolumn{5}{l}{ Dietary treatments } \\
& $\mathrm{T}_{1}$ & $\mathrm{~T}_{2}$ & $\mathrm{~T}_{3}$ & $\mathrm{~T}_{4}$ & SEM \\
& $0 \%$ & $0.20 \%$ & $0.40 \%$ & $0.60 \%$ & \\
\hline Initial weight & 36.67 & 36.67 & 36.67 & 39.50 & 0.11 \\
Final weight & 523.33 & 596.66 & 696.66 & 615.00 & 30.77 \\
Total wt. gain & 486.66 & 559.99 & 659.99 & 577.50 & 30.77 \\
Average wt. gain & 121.66 & 139.99 & 164.99 & 144.38 & 7.69 \\
Av. Daily wt. gain & 17.38 & 20.00 & 23.57 & 20.62 & 1.10 \\
Total feed intake & $2694.95^{\mathrm{a}}$ & $2160.68^{\mathrm{c}}$ & $2227.22^{\mathrm{b}}$ & $2673.20^{\mathrm{a}}$ & 74.36 \\
Weekly feed intake & $673.74^{\mathrm{a}}$ & $540.15^{\mathrm{c}}$ & $556.80^{\mathrm{b}}$ & $668.30^{\mathrm{a}}$ & 18.59 \\
Daily feed intake & $96.24^{\mathrm{a}}$ & $77.16^{\mathrm{c}}$ & $79.54^{\mathrm{b}}$ & $95.77^{\mathrm{a}}$ & 2.66 \\
Feed conversion ratio5.54 & 6.67 & $3.86^{\mathrm{b}}$ & $3.37^{\mathrm{b}}$ & $4.65^{\mathrm{ab}}$ & 0.47 \\
Mortality (\%) & 6.60 & 0.00 & 0.00 & 6.67 & 1.01 \\
\hline
\end{tabular}

a, b, means on the same row with different superscripts are significantly different.

Growth performance characteristics of broiler chickens (Finisher Phase)

The Total weight gain (Table 5) was significantly $(p<0.05)$ influenced by dietary treatments. The value obtained in this study ranged from 697.50-1086.15g. These values were lower than what was reported by Uchegbu et al (2010) and Afolayan et al. (2014). Average weekly weight gain and average daily weight gain follow the same trend as total weight gain of birds on control were superior while birds on diets with $0.40 \%$ methionine had the least significantly. Total feed intake, average weekly feed and average daily weight gain were significant influenced by dietary treatments. The quantity of feed consumed in this study did not agree with the report of Afolayan et al. (2014) and Uchegbu et al. (2010) apart from birds fed diets with $0.20 \%$ methionine whose consumption was comparable with the findings of these authors. Diet with $0.20 \%$ methionine resulted in better utilization of feed as these recorded the least fed conversion ratio of 4.50 though this was slightly higher than the range of $3.24-4.25$ reported by Afolayan et al. (2014) and 2.22-2.51 reported by Uchegbu et al. (2010). 
Table 5: Growth Performance Characteristics of Broiler Chickens Fed Graded Levels of Methionine in MaizeSoyabean Based Diet (Finisher Phase)

\begin{tabular}{llllll}
\hline $\begin{array}{l}\text { Parameters } \\
\text { (g/bird) }\end{array}$ & \multicolumn{5}{c}{ Dietary treatments } \\
& $\mathrm{T}_{1}$ & \multicolumn{5}{c}{} \\
& $(0 \%)$ & $\mathrm{T}_{2}$ & $\begin{array}{c}\mathrm{T}_{3} \\
(0.20 \%)(0.40 \%)(0.60 \%)\end{array}$ & $\mathrm{T}_{4}$ & SEM \\
\hline Initial weight & 523.33 & 596.66 & 696.66 & 615.00 & 30.76 \\
Final weight & 1609.46 & 1412.50 & 1394.16 & 1451.40 & 39.93 \\
Total wt. gain & $1086.13^{\mathrm{a}}$ & $815.83^{\mathrm{b}}$ & $697.50^{\mathrm{b}}$ & $836.40^{\mathrm{b}}$ & 49.16 \\
Average wt. gain & $271.53^{\mathrm{a}}$ & $203.96^{\mathrm{b}}$ & $174.37^{\mathrm{b}}$ & $209.10^{\mathrm{b}}$ & 12.29 \\
Av. Daily wt. gain & $38.79^{\mathrm{a}}$ & $29.13^{\mathrm{b}}$ & $24.91^{\mathrm{b}}$ & $29.87^{\mathrm{b}}$ & 1.76 \\
Total feed intake & $5387.27^{\mathrm{a}}$ & $3677.33^{\mathrm{b}}$ & $5347.97^{\mathrm{a}}$ & $5331.03^{\mathrm{a}}$ & 221.82 \\
Weekly feed intake & $1346.82^{\mathrm{a}}$ & $919.33^{\mathrm{b}}$ & $1336.99^{\mathrm{a}}$ & $1332.76^{\mathrm{a}}$ & 55.48 \\
Daily feed intake & $192.40^{\mathrm{a}}$ & $131.33^{\mathrm{b}}$ & $191.00^{\mathrm{a}}$ & $190.39^{\mathrm{a}}$ & 7.92 \\
Feed conversion ratio & $4.96^{\mathrm{b}}$ & $4.50^{\mathrm{b}}$ & $7.67^{\mathrm{a}}$ & $6.37^{\mathrm{a}}$ & 0.72 \\
Mortality (\%) & 20.00 & 16.67 & 26.67 & 30.00 & 1.72 \\
\hline \multicolumn{5}{c}{$\mathrm{a}, \mathrm{b}$, means on the same row with different superscripts are significantly different $(\mathrm{p}<0.05)$}
\end{tabular}

\section{Carcass characteristics}

The pre-slaughter weight (carcass weight) values (Table 6) were significantly $(P<0.05)$ influenced by dietary treatments. The values obtained for this study were however not in agreement with the range of 1.996.82$2072.93 \mathrm{~g}$ and $1760-2020 \mathrm{~g}$ reported by Ndelekwute et al. (2004) and Afolayan et al. (2014). The relative weight values obtained for drum stick were far lower than the ranges of $16.41-19.31 \%$ by Ndelekwute et al. (2014). The thigh weight was equally not in line with earlier findings reported in the range of $15.48-15.75,31.18$ -
32.29 and $17.22-18.73 \%$ reported by Onu et al. (2011), Hossaini-vashan et al. (2010) and Ndelekwute et al. (2014). The weight of Spleen and oesophagus were significantly $(p<0.05)$ influenced by dietary treatments. Birds on diets with $0.60 \%$ methionine produced significantly heavier spleen and oesophagus although statistically similar with what was obtained for those fed 0.20 and $0.40 \%$ methionine. The values obtained for spleen were at variance with the range of $0.08-0.20 \%$ reported by Ndelekwute et al. (2014).

Table 6: Carcass Characteristics of Broiler Chickens feed graded levels of synthetic Methionine in maize-soybean based diet.

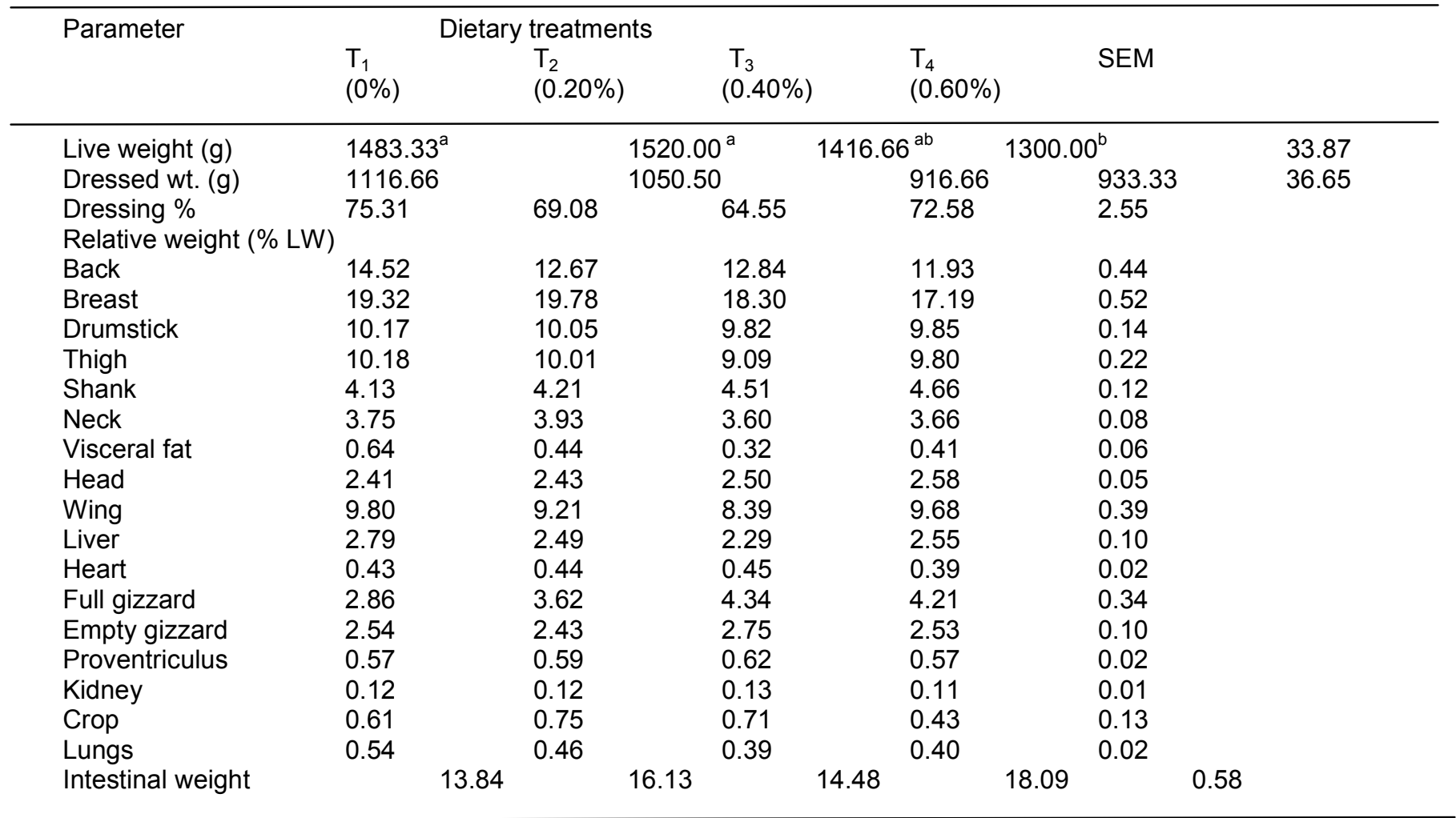


Blood characteristics (Haematology and serum biochemical indices)

The blood parameters were within the normal ranges for broiler chickens and indicated that the nutrients were adequately utilized by the broilers and posed no problem to the birds. The PCV, RBC, WBC, platelets and MCV obtained in this study were not significantly different across the treatments and within the normal range for chickens supported the finding of (Ikhiomioya et al., 2000). This shows that the bone marrows of the birds were functioning normally. The normal values of PCV obtained in this study showed that PCV increased the availability of protein, energy and the degradation of antinutritional factors. This improves broiler performance (Cary et al., 2002). This confirmed that haematological traits, especially $\mathrm{PCV}$ and $\mathrm{Hb}$ were correlated with the nutritional status of the animal (Adejumo, 2004) and agreed with Oyawoye and Ogunkunle, (1998) who stated that PCV is an index of toxicity in the blood and high-level usually suggest presence of toxic factors which has adverse effect on blood formation. The value obtained in this study for MCV is lower than the range of 92.44-122.09 reported by Akinola and Etuk (2015) but $\mathrm{MCHC}$ was within the range of $30.78-33.39$ by the same author. Monocyte was absent in $0.60 \%$ methionine. This is an indication that birds on $0.60 \%$ methionine were not stressed during the experiment by nutritional or environmental factors, since leucocytes responses are considered as better indicators of chronic stress (Siegel, 1995). The result therefore showed that basophils were absent in birds fed the control, birds on 0.20 and $0.60 \%$ methionine confirming the result of Maxwell and Robertson (1998) who stated that extreme stress conditions results in sasophilia.

Table 7: Haematological characteristics of Broilers fed graded levels of methionine in based diet.

\begin{tabular}{|c|c|c|c|c|c|}
\hline \multirow[t]{2}{*}{ Parameter } & \multirow[b]{2}{*}{$\begin{array}{l}\mathrm{T}_{1} \\
0 \%\end{array}$} & \multicolumn{3}{|c|}{ Dietary treatments } & \multirow[b]{2}{*}{ SEM } \\
\hline & & $\begin{array}{l}\mathrm{T}_{2} \\
0.20 \%\end{array}$ & $\begin{array}{c}\mathrm{T}_{3} \\
0.40 \%\end{array}$ & $\begin{array}{l}\mathrm{T}_{4} \\
0.60 \%\end{array}$ & \\
\hline Haemoglobin (g/dl) & 7.55 & 6.77 & 6.05 & 6.75 & 0.29 \\
\hline PCV (\%) & 22.75 & 20.50 & 18.25 & 20.25 & 0.86 \\
\hline Platelets $\left(10^{3} \mu / L\right)$ & 226.00 & 151.00 & 199.00 & 213.00 & 13.71 \\
\hline Lymphocytes (\%) & 72.50 & 69.50 & 68.00 & 68.00 & 1.07 \\
\hline Neutrophils (\%) & 22.50 & 25.00 & 24.50 & 29.00 & 1.26 \\
\hline Basophils (\%) & 0.00 & 0.00 & 0.50 & 0.00 & 0.13 \\
\hline Monocytes (\%) & 0.50 & 1.50 & 2.00 & 0.00 & 0.32 \\
\hline Eosinophils (\%) & 4.50 & 4.00 & 5.00 & 3.00 & 0.35 \\
\hline
\end{tabular}

$\mathrm{MCH}$ : Mean Corpuscular Haemoglobin

MCV: Mean Corpuscular Volume

$\mathrm{MCHC}$ : Mean Corpuscular Haemoglobin Concentration SEM: Standard Error Mean 
Table 8: Serum Biochemical Characteristics of Broiler Chickens Fed Graded levels of synthetic Methionine in Maizesoybean based-diets.

\begin{tabular}{|c|c|c|c|c|c|}
\hline \multirow[t]{2}{*}{ Parameter } & \multicolumn{3}{|c|}{ Dietary treatments } & \multirow[b]{2}{*}{$\begin{array}{l}\mathrm{T}_{4} \\
0.60 \%\end{array}$} & \multirow[b]{2}{*}{ SEM } \\
\hline & $\begin{array}{l}\mathrm{T}_{1} \\
0 \%\end{array}$ & $\begin{array}{l}\mathrm{T}_{2} \\
0.20\end{array}$ & $\begin{array}{l}\mathrm{T}_{3} \\
0.40 \%\end{array}$ & & \\
\hline Glucose $(\mathrm{mmol} / \mathrm{L})$ & 6.87 & 6.97 & 7.30 & 6.64 & 0.14 \\
\hline Cholesterol (mmol/L) & 4.89 & 6.81 & 5.36 & 5.63 & 0.37 \\
\hline Total protein $(\mathrm{g} / \mathrm{dl})$ & 5.24 & 5.66 & 5.45 & 6.33 & 0.11 \\
\hline Albumin $(\mathrm{g} / \mathrm{dl})$ & 3.24 & 3.40 & 3.49 & 3.41 & 0.06 \\
\hline Globulin (g/dl) & 2.00 & 2.26 & 1.96 & 1.92 & 0.07 \\
\hline Calcium $(\mathrm{mmol} / \mathrm{L})$ & 2.50 & 3.05 & 3.27 & 3.33 & 0.21 \\
\hline AST (U/I) & 16.85 & 31.50 & 27.50 & 34.00 & 4.28 \\
\hline ALT $(\mathrm{U} / \mathrm{I})$ & 19.00 & 25.00 & 25.00 & 23.00 & 1.31 \\
\hline Triglycerides (mmol/L) & 1.10 & 0.98 & 0.93 & 0.83 & 0.53 \\
\hline Chloride (mmol/L) & 101.75 & 99.10 & 103.85 & 103.60 & 0.36 \\
\hline Urea $(\mathrm{mmol} / \mathrm{L})$ & 4.14 & 4.82 & 4.07 & 4.15 & 0.14 \\
\hline $\mathrm{LDL}(\mathrm{mmol} / \mathrm{L})$ & 2.92 & 3.60 & 1.81 & 2.54 & 0.42 \\
\hline VLDL $\quad(\mathrm{mmol} / \mathrm{L})$ & 0.22 & 0.20 & 0.18 & 0.17 & 0.01 \\
\hline
\end{tabular}

AST- Aspartate transaminase

ALT- Alanine transaminase

HDL- High density lipoprotein

LDL- Low density lipoprotein

VLDL- Very low density lipoprotein

The result of the serum biochemical indices showed that blood protein was not significantly influenced by dietary treatments. The numerically higher value of blood protein was indicated in birds fed on $0.40 \%$ methionine. The values obtained in this study were within the normal range of serum protein $(4.55-6.46 \mathrm{~g} / \mathrm{dl})$ reported by Udoyong et al. (2010) except the value obtained for birds on $0-40 \%$ methionine but lower than $8.32-8.70 \mathrm{~g} / \mathrm{dl}$ reported by Njidda et al. (2006). Higher value indicates that there is enzyme hydrolysis of dietary proteins and explained that the blood pool serves as a major source of amino acids needed for the synthesis of protein (Scott, 1970, Njidda et al., 2006). This observation showed that the protein level in the diet was sufficient to sustain the normal protein levels in the blood. Blood cholesterol showed no significant difference among the treatment group, but the highest value was obtained for birds on $0.20 \%$ methionine while the control had the least. The values were higher than $3.10-3.64 \mathrm{mg} / \mathrm{dl}$ reported by Duwa et al, (2012) and 2.77-3.90mol/l reported by Akinola and Etuk, (2015). Blood calcium is the major factor in the formation and maintenance of the bones (Duwa et al., 2012). Minerals are known to be part of hormones and as activators of enzymes (NRC, 1977). Blood Glucose was not significantly influenced by the level of methionine in the diet. The highest was recorded for diet with $0.40 \%$ methionine while the least was recorded for those on $0.60 \%$ methionine. The values obtained in this study where not in agreement with the normal range of 9.9-11.1 $\mathrm{mmol} / \mathrm{l}$ stated by Banerjee, (2009) and 8.17-9.77 $\mathrm{mmol} / \mathrm{l}$ reported by Akinola and Etuk, (2015). Aspartate Transaminase (AST) was not significantly $(p>0.05)$ influenced by the level of methionine in the diet but diet with $0.60 \%$ methionine had the higher value of 34.00 followed by those on $0.20 \%, 0.40 \%$ with 31.50 and 27.50 respectively while birds on control diet had the least
(16.25). The values obtained in this study were higher than the range of 13.72-15.65 lu/c reported by Akinola and Etuk (2015). Alanine Transaminase (ALT) were not significantly $(p>0.05)$ influenced by dietary treatment. Similar values were obtained for diet on $0.20 \%$ methionine and $0.40 \%$ methionine. The least value was obtained for birds on control diet. The values obtained for this study were lower than the range of 104.79113.22 i.u/l. The similarity in the levels of AST and ALT showed that there was no liver damage by the diets. This was in line with the finding of Ekpenyong and Biobaku, (1986) who stated that the values of AST and ALT are normally low in blood but become high when there is occurrence of liver damage by toxic substances.

\section{CONCLUSION}

The results obtained in this study have showed that synthetic methionine has a high potential as feed ingredient in broiler diets, and that it can replace the expensive fish meal and other animal by -products in monogastric diets. The growth performance, haematological and serum biochemical and carcass characteristics were not adversely affected, indicating that the diets were adequately utilized with normal functioning of the internal organs.

\section{RECOMMENDATION}

This study recommends that farmers may do without fish meal and other animal by - products in line with the extant standards of the Animal Welfare Association. The quantity of expensive plant based proteins can also be reduced, but that up to $0.60 \%$ synthetic methionine can be included in broiler chickens diets without fear of compromising growth, blood and carcass characteristics. 


\section{REFERENCES}

Adejumo, D. O., 2004. Performance, organ development and haematological indices of rats fed sole diets of graded levels of cassava flour and soybean flour (Soyabean meal) as substitutes for energy and protein concentrates. Tropical Journal Animal Science 7, 57-63.

Afolabi, K. D., Akinsoyinii, A. O., Olajide, R and Akinleye, S. B., 2010. Haematological parameters of the Nigerian local grower chickens fed varying dietary levels of palm kernel cake. Proc. of the $35^{\text {th }}$ Annual Conf. of the Nig. Soc. for Anim. Prod., 247 -249.

Afolayan, S. B., Dafwang, I. I., Tegbe, T. S. B., Sekoni, A and Jegede, J. O., 2014. Performance of broiler chickens fed maize based diets substituted with graded levels of sweet potato meal. Nigeria Journal of Animal Production, 41, (1): 50-59.

Akinmutimi, A. H., 2003. Effect of processing on metaboliszability of energy content of Sword beans (Canavalia gladiata) using broiler chicks (starter phase). Proceedings of the $28^{\text {th }}$ Annual Conf. of the Nig. Soc. for Anim. Prod. (NSAP), Ibadan, Nigeria, pp:194-196.

Akinola, L. A. F and Etuk, M. O., 2015. Haematological and Serum Biochemical Responses of Broilers Fed Varying Levels of Indomie Waste-Based Diets. Journal of Agriculture and Veterinary Science. 8(1): 66-70 www.iosrjournals.org

Amaefule, K. U and Onwudike, O. C., 2003. Comparative evaluation of the processing methods for pigeon pea seeds (Cajanuscajan) as protein source for broilers. Journal of Sustainable Agriculture and Environment, 1:134-138.

Ani, A. O and Okeke, G. C., 2003. The substitution of pigeon pea (Cajanus cajan) seed meal for soybean meal in broiler finisher rations. Proc. $8^{\text {th }}$ Annual Conference of Anim. Sci. Ass. Of Nig. (ASAN), Univ. of Tech. Minna, Nigeria, Pp.1012.

AOAC., 2000. Official method of Analysis $19^{\text {th }}$ Edition Association of official Analytical Chemists, Washington, D.C, USA.

Apata, D. F and Ojo, V., 2000. Efficacy of the Trichordema viride Enzyme complex in broiler starter fed cowpea Testa Based Diets. Book of Abstracts, Nigerian Society of Animal Production, Pp. 132-133.

Banerjee, G. C. A., 2009. Textbook of Animal Husbandry, $8^{\text {th }}$ ed., Oxford and IBH Publishing Co. PVT. Ltd., New Delhi, India. Pp.118-139.

Cary, N. H., Williams, P. E. V., Geraet, P. A., Uzu, G and Annison, G., 2002. Factors affecting non-starch polysaccharide digestibility in poultry. Rhone
Poulen. Animal Nutrition, 42 Ar. Aristide Briand BP 10092 164. Antony Cedex, France.

Church, D. C., 1991. Livestock feeds and feeding, $3^{\text {rd }}$ edition, Prentice hall Incorporation cliffs, New Jersey. U.S.A. P:465.

Dacie, J. V and Lewis, S. M., 1991. Practical Haematology, $7^{\text {th }}$ Edition, Edinburgh: Churchill living stone.

Dafwang, I. I., 2006. Meat eggs and milk from Farm Waste Exploration in Animal Nutrition Research and Extension. An inaugural Lecture. University of organized lectures committee, Vice chancellor's Office, Ahmadu Bello University, Zaria.

Deng, K., Wong, C. W and Nolan, J. V., 2007. Carryover effects of early-life supplementary methionine on lymphoid organs and immune responses in egg-laying strains chickens. Animal Feed Science Technology, 76:544-552.

Duwa, H. E., Oyawoye, O and Njidda, A. A., 2012. Haematological Responses and Serum Biochemical Indices of broilers Fed Differently Processed Sorrel Seed (Hibiscus Sabdariffia) Meal in Semi-Arid Region of Nigeria. British Journal of Poultry Sciences 1(1): 05-10.

Ekpenyong T. E and Biobaku, W. O., 1986. Growth response of rabbits fed activated sewage sludge and dry poultry waste. Journal of Rabbit Research. 9 (1): 14-16.

Emenalon, O. O and Udedibie, A. B. I., 1998. Effect of dietary raw, cooked and toasted mecuna prusiens seeds (velvet bean) on the performance of finisher broiler. Nigeria Journal Animal Production, 25:115-119.

Esonu, B. O., Ihenkwumere, F. C., Iwuji, T. C., Akamu, $\mathrm{N}$ and Nwugo, O. H., 2003. Evaluation of microder mispuberula leaf meal as an ingredient in broiler starter diets. Nig. J. Anim. Prod. (30). 3-8.

Etuk, E. B and Udedibie, A. B. I., 2003. Effect of cooked pigeon pea (Cajanus cajan) seed meal on the performance of broiler chicks. J. Agric. Social Res., 3(1) 1-12.

Fancher, B. I and Jesen, L. S., 1989. Influence on performance on three to six weeks old broilers of varying dietary protein contents with supplementation of essential amino acids requirements. Poultry science: $68: 113-123$.

Hosseini-Vashan, S. J., Jafari-Sayadi, A. R., Golian, A., Motaghiia, G. H. Namvari, M and Hamedi, M., 2010. Comparison of growth performance and carcass characteristic of broiler chickens fed diets with various energy and cost ant energy to protein ratio. Journal of Animal and Veterinary Advances 9(20): 2565-2576. 
Ikhimioye, A. A., Oleku, I. T and Ahmed, M., 2000. Preliminary investigation on the haematological of the Nigerian indigenous chicken. Proceeding of $5^{\text {th }}$ Annual Conference of Animal Science Association of Nigeria, Port Harcourt, 10-12.

Jain, N. C., 1986. Schalm's Veterinary Haematology $\left(4^{\text {th }}\right.$ edition). Lea and Fibiger Philadelphia, United State of America.

Kalbande, V. H., Ravikanth, K., Maini, S and Rekhe, D. S., 2009. Methionine Supplementation options in poultry. International Journal of Poultry Science $8(6)$ : 588-591.

Kecici, D. C., Kumar, R and Duffin, J. M., 1998. Chemical Enzymology. In: clinical Biochemistry of domestic Animals: Academic press. Boston, Massachuset, Pp. 303-325.

Kelly, S. M., 1980. Haematology in Avians. EBSC Churchill Livingstone, $3^{\text {rd }}$ Edition, London.

Madubuike, F. N and Ekenyen, B. U., 2006. Haematology and Serum biochemistry Characteristics of Broiler Chicks Fed Varying Dietary Levels of Ipomoea asarifolia Leaf meal. International J. Poultry Sci., 5(1):9-12

Maxwell, M. H and Robertson, G. W., 1998. The avian heterophil leucocytes: A review, World's Poultry Science Journal, 54; 155-178.

Mmerole, F. U. C., 1996. The haematological parameters in the Nigeria Local Chicken. Nigeria Journal of Animal Production, 23(1), 9497.

NRC., 1977. National Research Council, Nutrient Requirements of Poultry. National Academy of Sci., 5(1): 9-12. Science, Washington, D. C., 1:2-10.

Ndelekwute, E. K., Amaefule, K. U., Uzegbu, H. O. and Okereke, C. O., 2013. Effect of finisher diets treated with organize acids on carcass and internal organs of broiler chickens. Nigerian Journal of Animal Production 39(10): 190-198.

Ndelekwute, E. K., Uzegbu, H. O., Amaefule, K. U., Okereke, C. O and Umoh, B. T., 2014. Effect of organic acid fed through drinking water on carcass and internal organs of broiler chickens. Nigeria Journal of Animal Production 41(1):60-67.

Njidda, A. A., Igwebike, J. U., Ngoshe, A. A and Tijjani, A. O., 2006. Effect of substituting maize with graded levels of cane molasses on the performance of broiler finisher birds in the semi- arid region of Nigeria, J. Sustainable Agric. Environ, 8(1):1-13.

Nwocha, L. A., Agbabiaka, K. U., Anukam and Beketin,

T. O., 2014. Growth responses, carcass and blood characteristics of finisher broilers fed sorghum off a meal as dietary supplement. International Journal of Agric. Science. 4(7), 392-398.

North, M. O and Bell, D. D., 1990. Commercial chicken production manual. $4^{\text {th }}$ edition. Van Norstrand Reinhold, New York, USA.

Ogunfowora, O., 1984. Structure, cost and rations in feed management. Training workshop, Dept. of Agric Economics, University of Ibadan, Nigeria. April 10- May, 02.

Olomu, J. M., 1995. Monogastric Animal Nutrition: Principle and Practice. A Jachen publication, 73.

Onu, P. N., Madubuike, F. N., Nwakpu, P. E and Anyachie, A. I., 2011. Performance and carcass characteristics of broilers raised on three different litter materials. Agriculture and Biology Journal of North America ISSN Print Online: 2151-7525.

Oyawoye, E. O and Ogunkunle, M., 1998. Chemical analysis and biochemical effects of raw beans on broiler. Proceeding of Nigerian Society for Animal Production, 141-142.

Scott, A., 1970. Absorption of carbohydrate and protein metabolism. In: Duke's Physiology of Domestic Animals. 18 edn. (Swenson, M. J. edns). Cornell University Press Limited, London.

Siegel, H. S., 1995. Stress, strain and resistance. British Poultry Science, 36(1): 3-22.

Steel, R. G. D and Torrie, J. H., 1980. Principles and procedures of statistics. A biometric approach. $2^{\text {nd }}$ edition, McGraw Hill Book Co. Inc, New York U.S. A.

Swain, B. K and Johri, T. S., 2000. Effect of supplemental methionine, chorine and their combinations on the performance and immune responses of broilers. Poultry Science, 41:8388.

Uchegbu, M. C., Omede, A. A., Chiedozie, I. C., Nwaodu, C. H and Ezeokeke, C. T., 2010. Performance of Finisher Broilers fed varying levels of raw(sundried) Cocoyam (Xanthosoma sagititifolium) Corm Meals. Report and Opinion, 2(8): 22-25.

Udoyong, A. O., Kibon, A., Yakubu, S. M., Yakubu, B. Augustine, C and Isaac, L., 2010. Haematological responses and erum biochemistry of broiler chicken fed graded levels of enzyme (Maxigrain) supplemented cassava a peel meal (CPM) based diets. Global J. Biotech. Biochem., 5(2): 116-119. 
